\title{
CDKN1A-interacting zinc finger protein 1 is a novel biomarker for lung squamous cell carcinoma
}

\author{
XIAOJUN ZHOU ${ }^{1}$, QIANG LIU ${ }^{2}$, YOUICHIRO WADA ${ }^{3,4}$, LIN LIAO $^{1}$ and JU LIU ${ }^{2}$ \\ ${ }^{1}$ Department of Endocrinology; ${ }^{2}$ Laboratory of Microvascular Medicine, Medical Research Center, \\ Shandong Provincial Qianfoshan Hospital, Shandong University, Jinan, Shandong 250014, P.R. China; \\ ${ }^{3}$ The Research Center for Advanced Science and Technology; ${ }^{4}$ Isotope Science Center, The University of Tokyo, \\ Tokyo 153-8904, Japan
}

Received May 30, 2016; Accepted September 22, 2017

DOI: $10.3892 / \mathrm{ol} .2017 .7282$

\begin{abstract}
CDKN1A-interacting zinc finger protein 1 (CIZ1), a nuclear protein that participates in DNA replication, is involved in the pathogenesis of several types of cancer. However, the role of CIZ1 in lung squamous cell carcinoma (LSCC) is not fully understood. In the present study, the expression of CIZ1 in tissue microarrays and surgical samples of human LSCCs was examined. CIZ1 expression was found to be significantly increased in LSCC tissues compared with adjacent tissues or normal controls, whereas expression of a CIZ1-interacting protein, $\mathrm{p} 21^{\mathrm{Cip} 1 / \mathrm{Waf} 1}$, was decreased. CIZ1 staining intensity and CIZ1-positive vascular invasion were positively correlated with at least two categories of the Tumor-Node-Metastasis (TNM) staging system ( $\mathrm{T}$ stage, $\mathrm{N}$ stage or TNM stage). It was also observed that CIZ1 was specifically expressed in the vascular cells of LSCC tissues. These results indicate that overexpression of CIZ1 may contribute to the growth and angiogenesis of LSCC, thus CIZ1 could represent a biomarker for diagnosis and a target for therapeutic intervention.
\end{abstract}

\section{Introduction}

Lung squamous cell carcinoma (LSCC), which accounts for $40 \%$ of non-small cell lung cancer cases, causes $\sim 400,000$ cases of cancer-associated mortality worldwide annually (1). LSCC is derived from the metaplasia of bronchial epithelial cells,

Correspondence to: Professor Lin Liao, Department of Endocrinology, Shandong Provincial Qianfoshan Hospital, Shandong University, 16766 Jingshi Road, Jinan, Shandong 250014, P.R. China

E-mail: liaolin@medmail.com.cn

Dr Ju Liu, Laboratory of Microvascular Medicine, Medical Research Center, Shandong Provincial Qianfoshan Hospital, Shandong University, 16766 Jingshi Road, Jinan, Shandong 250014, P.R. China E-mail: ju.liu@sdu.edu.cn

Key words: CDKN1A-interacting zinc finger protein 1, lung squamous cell carcinoma, $2^{\text {Cipl/Waf1 }}$, angiogenesis and is characterized by the presence of cavitary lesions in the proximal bronchus and keratin pearls in the center of the tumors (2). The large LSCCs may undergo central necrosis and cavitation due to the lack of blood supply (2). At early stages of the disease, LSCC usually develops without evident symptoms and can barely be detected using radiographic methods (2). Although the diagnosis and treatment of cancer has greatly improved in recent decades, the prognosis of LSCC remains dismal, as $<15 \%$ of diagnosed patients survive for $>5$ years (3). The failure of early diagnosis and a lack of targeted therapy are the primary obstacles for the treatment of LSCC. Therefore, investigating novel biomarkers for early diagnosis or targeted therapy would be beneficial in improving survival rates in LSCC patients.

CIZ1 (Cdkn1A-interacting zinc finger protein 1) was first identified as a protein that interacts with the cyclin $\mathrm{E} / \mathrm{p} 21^{\text {Cip1/Waf1 }}$ complex in a yeast-2-hybrid screening (4). Recent studies revealed that CIZ1 mainly exerts its biological roles in DNA replication initiation and cell cycle regulation (5). CIZ1 mediates the assembly of the pre-replication and pre-initiation complexes by interacting with cyclin $\mathrm{E}$, cyclin A, CDK2 cyclin-dependent kinase 2 (CDK2), cell division cycle 6 (CDC6) and proliferating cell nuclear antigen (PCNA) in the $\mathrm{G}_{1}$ phase (6-8). Knockdown of CIZ1 disrupts DNA replication and causes cell cycle arrest at the $G_{1}$ phase (6). CIZ1 also participates in the development of a number of cancer types. Overexpression of CIZ1 has been observed in samples of colon cancer (9), gallbladder cancer (10), prostate carcinoma (11), gastric cancer (12) and undifferentiated embryonic sarcoma of the liver (13). The expression level of CIZ1 is negatively associated with the survival rate of patients with colon cancer (9). In lung cancer, the CIZ1 b-variant is specifically overexpressed in non-small cell lung cancer samples compared with adjacent tissues or small cell lung cancer samples. Non-small cell lung cancer can be efficiently distinguished from benign lung nodules with an accuracy of 95\% by detecting the expression level of CIZ1 b-variant (14).

The role of CIZ1 in the development of cancer may be associated with its interacting proteins (5). p2 $1^{\text {Cip1/Waf1 }}$, one of the first CIZ1-interacting proteins that were identified, is a well-known regulator of the cell cycle that directly binds to and inactivates CKD2. The binding of CIZ1 alters the subcellular 
distribution of $\mathrm{p} 21^{\mathrm{Cip} 1 / \mathrm{Waf} 1}$ in cells by promoting the translocation of $\mathrm{p} 21^{\mathrm{Cip} 1 / \mathrm{Waf} 1}$ from the nucleus to the cytoplasm (4). $\mathrm{p} 21^{\mathrm{Cip} 1 / \mathrm{Waf} 1}$ expression is positive in $35-80 \%$ of non-small cell lung cancer cases (15-18). Patients who are positive for $\mathrm{p} 21^{\mathrm{Cip} 1 / \text { Waf1 }}$ expression survived significantly longer compared with those negative for $\mathrm{p} 21^{\mathrm{Cip} 1 / \text { Waf } 1}$ expression, indicating that $\mathrm{p} 21^{\mathrm{Cip} 1 / \mathrm{Waf} 1}$ is a favorable prognostic factor for non-small cell lung cancer (15-17).

In the present study, a set of tissue microarray data and fresh surgical samples were utilized to examine CIZ1 expression in LSCC tissues, as well as in normal controls. The results of the present study revealed that CIZ1 expression was significantly increased in LSCC tissues compared with adjacent normal tissues, while $\mathrm{p} 21^{\text {Cip1/Waf1 }}$ expression displayed a contrary pattern. The expression level of CIZ1 and CIZ1-positive vascular invasion in LSCC were, using the Tumor-Node-Metastasis (TNM) staging system (19), positively correlated with the T stage, $\mathrm{N}$ stage or overall TNM stage. CIZ1 was specifically expressed in the endothelial cells of microvessels in LSCC. These data suggest that overexpression of CIZ1 might contribute to the growth, angiogenesis and metastasis of LSCC.

\section{Materials and methods}

Tissue samples. The present study was performed in accordance with the 'Code for Proper Secondary Use of Human Tissue'. The fresh samples from 3 male LSCC patients with a mean age of 65.7 years (range, 56-74 years) were obtained from Shandong Provincial Qianfoshan Hospital (Jinan, China) between January 2014 and January 2016. The tissue microarrays (TMAs) were purchased from US Biomax, Inc. (BC041115b; Rockville, MD, USA), which included specimens from 41 LSCC patients and 9 normal individuals. The clinical information of the specimens was provided by the manufacturer. The present study was approved by the Ethics Committee of Shandong Provincial Qianfoshan Hospital, and written informed consent was provided by all patients.

Immunohistochemistry. After blocking with 5\% goat serum (OriGene Technologies, Inc., Beijing, China) for $30 \mathrm{~min}$ at room temperature, immunohistochemical staining was performed on the TMAs at a section thickness of $5 \mu \mathrm{m}$ using rabbit polyclonal anti-CIZ1 antibody (cat. no. ab102013, Abcam, Cambridge, MA, USA) with a dilution of 1:600 at $4^{\circ} \mathrm{C}$ overnight. Following washing with $1 \mathrm{X}$ phosphate-buffered saline, the sections were incubated with biotinylated anti-mouse secondary antibody (cat.no. TA130008; OriGene Technologies, Inc.; dilution, 1:100) for $30 \mathrm{mins}$ at room temperature, followed by the streptavidin-peroxidase method according to the manufacturer's protocol (A0303; Beyotime Institute of Biotechnology, Shanghai, China). DAB Peroxidase (HRP) Substrate kit (SK-4100; Vector, Burlingame, CA, USA) was used to visualize the sections. Counterstaining was performed with hematoxylin (Beyotime Institute of Biotechnology) prior to mounting of the samples onto coverslips. The negative control was prepared using the same protocol but without primary antibody incubation. Following staining, images of the TMAs were captured using a fluorescence microscope (FSX100; Olympus Corporation, Tokyo, Japan) and analyzed using ImagePro Plus 6.0 software (Media Cybernetics, Silver Spring, MD, USA). The parameters, percentage of positive expression and staining intensity, were calculated to evaluate CIZ1 expression as previously described (9).

Western blot analysis. LSCC tissues or adjacent normal lung tissues were lysed in Giordano buffer (50 mM Tris- $\mathrm{HCl}$, pH 7.4, 250 mM NaCl, 0.1\% Triton X-100, 5 mM EDTA) or 1xLaemmli buffer (10\% glycerol, $100 \mathrm{mM}$ DDT, $62.5 \mathrm{mM}$ Tris-base) containing phosphatase and protease inhibitors (Sigma-Aldrich, Merck KGaA, Darmstadt, Germany). The protein concentration was determined using the Bio-Rad DC Protein Assay kit (Bio-Rad Laboratories, Inc., Hercules, CA, USA), and $30 \mu \mathrm{g}$ of each sample (per lane) was separated by $10 \%$ SDS-PAGE and transferred to a polyvinylidene difluoride membrane (EMD Millipore, Billerica, MA, USA). The membranes were blocked with 5\% non-fat milk in Tris-buffered saline containing $0.05 \%$ Tween (TBS-T) for $1 \mathrm{~h}$ at room temperature, and then incubated overnight at $4^{\circ} \mathrm{C}$ with the primary antibody. The next day, the membranes were washed three times with TBS-T and incubated with horseradish peroxidase-labeled goat anti-rabbit secondary antibody (1:5,000; cat. nos. TA140002 and TA130023; OriGene Technologies, Inc.). Following this, the membranes were washed with TBS-T again, and the luminescent signal was detected using the FluorChem E enhanced chemiluminescent system (ProteinSimple, San Jose, CA, USA). Each experiment was repeated 3 times. The primary antibodies used were rabbit anti-CIZ1 antibody (1:1,000; cat. no. ab102013; Abcam), rabbit anti-p21 ${ }^{\text {Cip1/Waf1 }}$ antibody (1:1,000; cat. no. ab109520; Abcam) and anti- $\beta$-actin antibody (1:1,000; cat. no. A1978, Sigma-Aldrich; Merck KGaA). The band intensity was quantified by ImageJ 1.48 software (National Institutes of Health, Bethesda, MD, USA).

Immunofluorescence microscopy. Lung SCC tissues or adjacent normal lung tissues were processed for double immunofluorescence staining to detect vascular expression of CIZ1, as described previously (20). The tissue sections were simultaneously incubated with rabbit polyclonal anti-CIZ1 (1:300; cat. no. ab102013; Abcam) and fluorescein isothiocyanate (FITC)-conjugated smooth muscle actin ( $\alpha$-SMA; 1:100; cat. no. ab8211, Abcam, Cambridge, MA, USA). Immunoreaction was visualized by incubation with an Alexa Fluor-488 dye-conjugated goat anti-rabbit IgG secondary antibody (1:200; cat. no. A31627; Invitrogen; Thermo Fisher Scientific, Inc., Waltham, MA, USA). Following nuclear staining with DAPI (Beyotime Institute of Biotechnology), the sections were sealed, and images were captured using a fluorescence microscope (FSX100; Olympus Corporation).

Statistical analysis. Paired t-tests were used to analyze the level of CIZ1 protein expression. In addition, Spearman's rank correlation coefficient analysis was used to validate the correlation coefficients of vascular invasion, expression area and intensity of CIZ1 with age, sex, and T stage, N stage and TNM stage of the TNM staging system. All statistical analysis was performed using SPSS 20.0 software (BM Corp., Armonk, $\mathrm{NY}$, USA), and $\mathrm{P}<0.05$ was considered to indicate a statistically significant difference. 


\section{Results}

CIZ1 is overexpressed in LSCC. Immunohistochemistry of CIZ1 on TMAs was performed to examine the association between CIZ1 protein expression and LSCC. In the lung tissues of normal individuals, CIZ1 staining was weak or absent (Fig. 1A). However, strong staining for CIZ1 was observed in LSCC tumor cells at all stages (Fig. 1B-D). CIZ1 is mainly localized in the nucleus of the adjacent normal tissues, but strong staining was exhibited in the nucleus and cytoplasm of LSCC tumor cells (Fig. 1B-D). Next, the level of CIZ1 expression in fresh LSCC tissues was determined. Western blot analysis revealed that CIZ1 levels were markedly increased in all three pairs of tested samples compared with the adjacent normal tissues (Fig. 2A). Statistical analysis demonstrated that CIZ1 expression was increased by $\geq 3$-fold in LSCC tissues compared with the adjacent normal tissues (Fig. 2B). These results indicate that CIZ1 expression was upregulated in LSCC cells.

CIZ1 expression is correlated with clinicopathological parameters of LSCC. Spearman's rank correlation coefficient test was used to analyze the correlation between CIZ1 expression profile and LSCC clinicopathological parameters, including age, sex, $\mathrm{T}$ stage, $\mathrm{N}$ stage and TNM stage of the TNM staging system. CIZ1-positive vascular invasion was correlated with $\mathrm{N}$ stage $(\mathrm{r}=0.289, \mathrm{P}<0.05)$ and $\mathrm{TNM}$ stage $(\mathrm{r}=0.520, \mathrm{P}<0.01)$. The CIZ1 staining intensity was correlated with $\mathrm{T}$ stage $(\mathrm{r}=0.851, \mathrm{P}<0.01)$ and $\mathrm{TNM}$ stage $(\mathrm{r}=0.354$, $\mathrm{P}<0.05)$. CIZ1-positive area was correlated with $\mathrm{T}$ stage $(\mathrm{r}=0.431, \mathrm{P}<0.01), \mathrm{N}$ stage $(\mathrm{r}=0.355, \mathrm{P}<0.01)$ and $\mathrm{TNM}$ stage $(\mathrm{r}=0.477, \mathrm{P}<0.01)$. No significant correlation was identified between CIZ1-positive vascular invasion, CIZ1-positive area, CIZ1 staining intensity and age $(r=-0.032,0.072$, -0.085 , respectively; $\mathrm{P}>0.05)$, or sex $(\mathrm{r}=0.033,-0.146,-0.146$, respectively; $\mathrm{P}>0.05$ ) (Table I). These analyses implied that CIZ1 might be involved in the growth, angiogenesis and metastasis of LSCC.

CIZ1 is specifically expressed in vasculature of LSCC. Since CIZ1-positive vascular invasion was significantly correlated with $\mathrm{N}$ stage and TNM stage of LSCC, the expression of CIZ1 was assessed in blood vessels of fresh surgical samples of LSCC. As shown in Fig. 3A, no expression of CIZ1 was observed in the vasculature of adjacent normal tissues, whereas it was abundantly expressed in the inner layer of the vascular lumen of the LSCC tissues. To identify the location of CIZ1 in microvessels, an anti- $\alpha$-SMA antibody was used to distinguish the vascular smooth muscle cells and double immune fluorescence staining was performed. Consistent with the results observed in Fig. 3A, CIZ1 staining was absent in the blood vessels of adjacent normal tissues, but was clearly observed in vascular smooth muscle cells and endothelial cells of the LSCC samples (Fig. 3B). Thus, CIZ1 expression was restricted to the vasculature of LSCC.

CIZ1-interacting protein $221^{\text {Cipl/Wafl }}$ was downregulated in LSCC samples. $21^{\text {Cip1/Waf } 1}$, the first identified protein to interact with CIZ1 (4), is dysregulated in a number of cancer types.
A

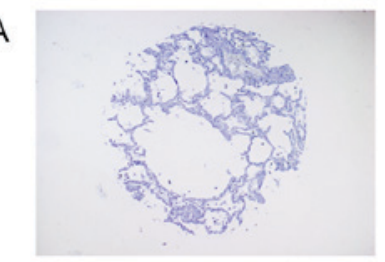

B

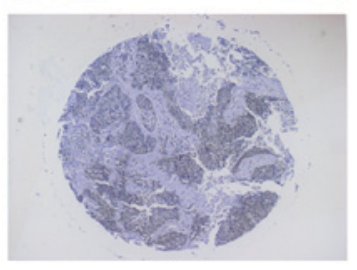

C

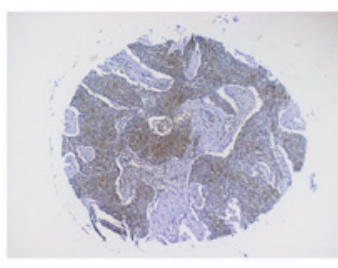

D
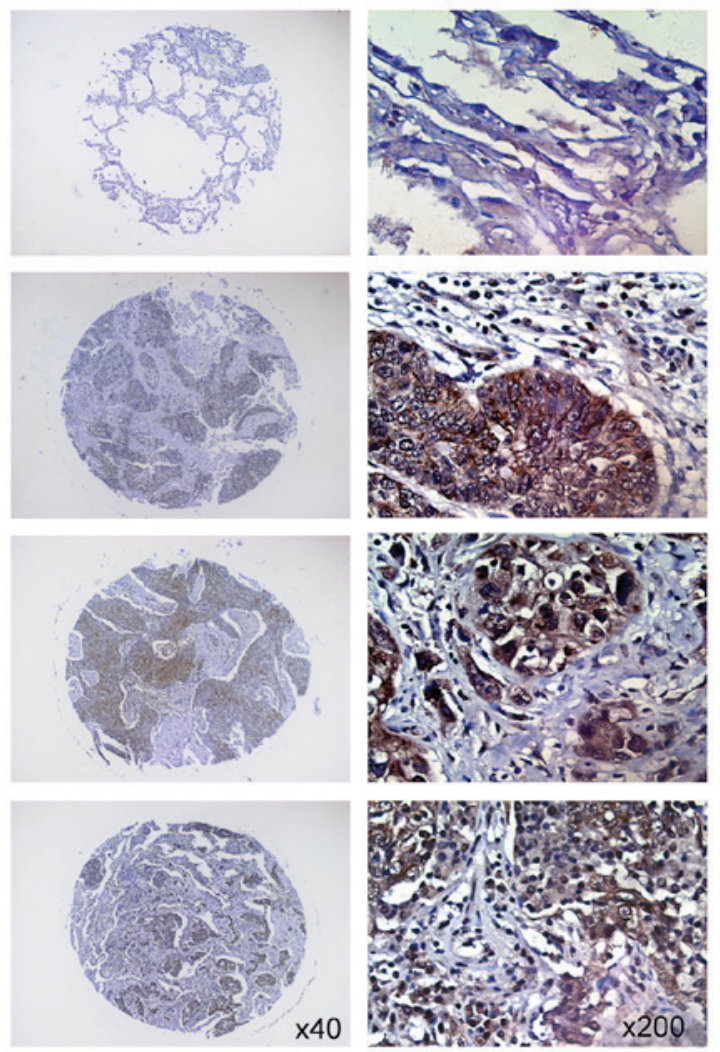

$\times 40$

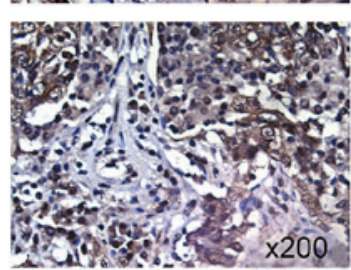

Figure 1. CIZ1 expression in tissue microarrays of lung squamous cell carcinoma samples. Representative images of CIZ1 immunohistochemistry on (A) adjacent normal tissue, (B) well, (C) moderately and (D) poorly differentiated LSCC tissues. Magnification, x40 (left panels) and x200 (right panels). CIZ1, CDKN1A-interacting zinc finger protein 1.

A

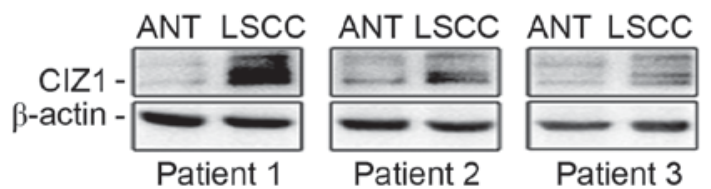

B

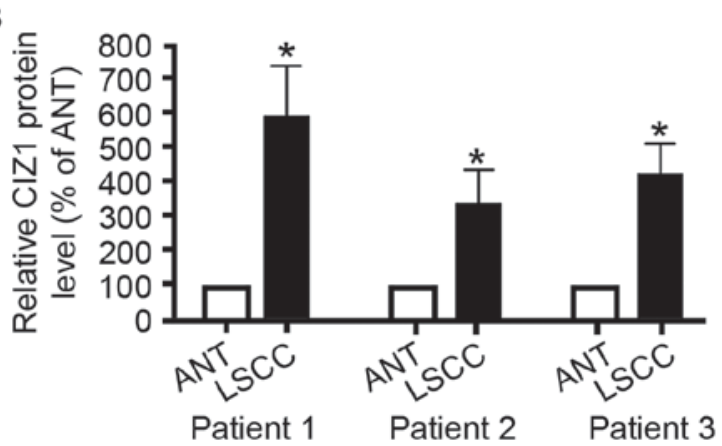

Figure 2. CIZ1 expression in fresh LSCC surgical samples. (A) Representative immunoblots of CIZ1 and $\beta$-actin of protein samples extracted from three pairs of LSCC tissues and ANT. $\beta$-actin was used as the internal control. (B) Densitometry analysis of the blots of CIZ1 and $\beta$-actin. $n=3 ;{ }^{*} \mathrm{P}<0.05$. CIZ1, CDKN1A-interacting zinc finger protein 1; LSCC, lung squamous cell carcinoma; ANT, adjacent normal tissue.

The deficiency of $\mathrm{p} 21^{\mathrm{Cip} 1 / \text { Waf } 1}$ induces the proliferation of tumor cells and cancerous angiogenesis (20). To investigate whether CIZ1 overexpression affected the level of $\mathrm{p} 21^{\text {Cip1/Waf1 }}$ protein in LSCCs, western blot analysis was performed to detect 
Table I. Correlation of CIZ1 expression and clinicopathological parameters of lung squamous cell carcinoma.

\begin{tabular}{|c|c|c|c|}
\hline \multirow{2}{*}{$\begin{array}{l}\text { Clinicopathological } \\
\text { characteristics }\end{array}$} & \multicolumn{3}{|c|}{ r-value } \\
\hline & CIZ1-positive vascular invasion & CIZ1 staining intensity & CIZ1-positive area \\
\hline Age & $-0.032^{\mathrm{c}}$ & $-0.085^{\mathrm{c}}$ & $0.072^{\mathrm{c}}$ \\
\hline Sex & $0.033^{\mathrm{c}}$ & $-0.146^{\mathrm{c}}$ & $-0.146^{\mathrm{c}}$ \\
\hline T stage & $0.105^{\mathrm{c}}$ & $0.851^{\mathrm{b}}$ & $0.431^{\mathrm{b}}$ \\
\hline $\mathrm{N}$ stage & $0.289^{\mathrm{a}}$ & $0.270^{\mathrm{c}}$ & $0.355^{\mathrm{b}}$ \\
\hline TNM stage & $0.520^{\mathrm{b}}$ & $0.354^{\mathrm{a}}$ & $0.477^{\mathrm{b}}$ \\
\hline
\end{tabular}

${ }^{\mathrm{a}} \mathrm{P}<0.05,{ }^{\mathrm{b}} \mathrm{P}<0.01,{ }^{\mathrm{c}} \mathrm{P}>0.05$. CIZ1, CDKN1A-interacting zinc finger protein 1 ; TNM, tumor-node-metastasis.

A

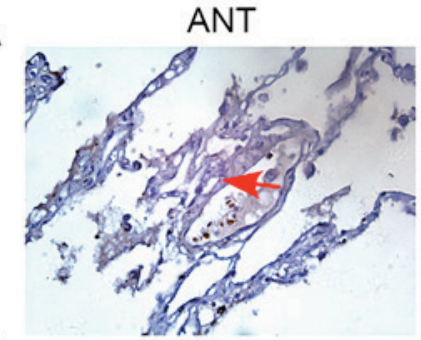

B

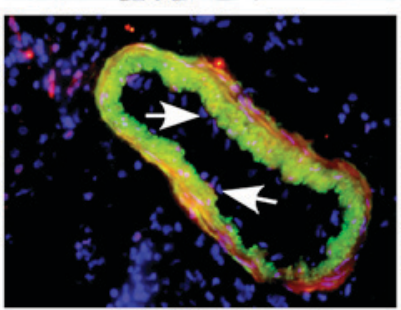

LSCC
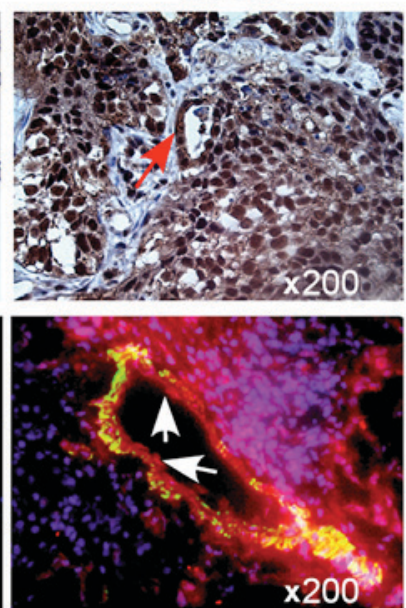

Figure 3. CIZ1 expression in vascular cells of LSCC. (A) Immunohistochemistry of CIZ1 on blood vessels of ANT (left) and LSCC (right). Arrows indicate microvessels in lung tissues. (B) Double immunofluorescence staining of CIZ1 (red) and $\alpha$-smooth muscle actin (green) on ANT (left) and LSCC tissue (right). The arrows refer to endothelial cells of the blood vessels in lung tissues. Magnification, x200. CIZ1, CDKN1A-interacting zinc finger protein 1; LSCC, lung squamous cell carcinoma; ANT, adjacent normal tissue.

p21 $1^{\text {Cipl/Waf1 }}$ in fresh surgical samples. As shown in Fig. 4A and $\mathrm{B}$, the level of $\mathrm{p} 21^{\mathrm{Cip} / \text { /Wafl }}$ protein was significantly decreased in LSCC tissues compared with adjacent normal tissues in all 3 samples. This result indicated that the interaction of CIZ1 and $\mathrm{p} 21^{\mathrm{Cip} 1 / \text { Wafl }}$ might contribute to the development of LSCC.

\section{Discussion}

LSCC is the second leading cause of lung cancer-associated mortalities (1). The lack of biomarkers and therapeutic targets in LSCC hinders the development of novel treatments. The present study provided support for the increase of CIZ1 expression in LSCC samples compared with normal adjacent tissues. The CIZ1 staining intensity and CIZ1-positive area was correlated with LSCC TNM staging. CIZ1 was specifically expressed in vasculature of LSCC. The expression of p21 $1_{\text {Cip1/Waf1 }}$, a CIZ1-interacting protein, was reduced in LSCC compared with adjacent normal tissue. Together, these results indicate that CIZ1 might be involved in LSCC development

A

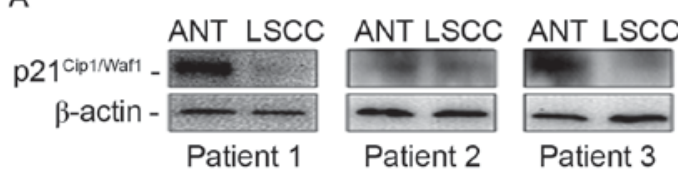

B

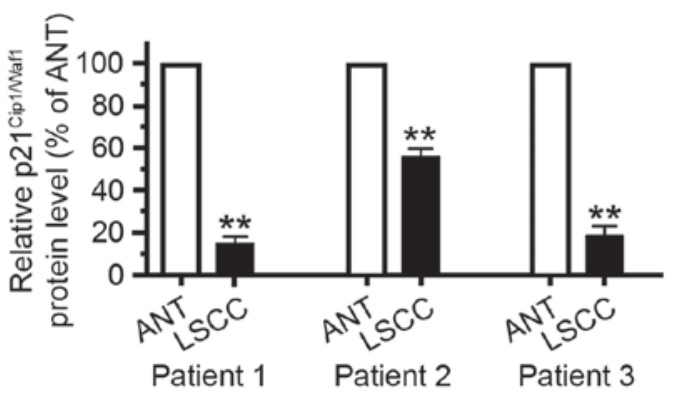

Figure 4. p21 $1^{\text {Cip } 1 / \text { Waf1 }}$ expression in fresh LSCC surgical samples. (A) Representative immunoblots of $\mathrm{p} 21^{\text {Cip//Wafl }}$ and $\beta$-actin of protein samples extracted from three pairs of LSCC tissues and ANT. $\beta$-actin was used as the internal control. (B) Densitometry analysis of the blots of $\mathrm{p} 21^{\mathrm{Cip} 1 / \text { Wafl }}$ and $\beta$-actin. $n=3 ;{ }^{* *} \mathrm{P}<0.01$. LSCC, lung squamous cell carcinoma; ANT, adjacent normal tissue.

and may emerge as a novel biomarker and therapeutic target for LSCC.

The present study revealed that CIZ1 is overexpressed in LSCC cells, which indicates that CIZ1 might contribute to the development of LSCC. CIZ1 functions in the formation of pre-replication complex and pre-initiation complex by recruiting cyclin E, cyclin A, CDK2, CDC6 and PCNA (6-8). Interfering with CIZ1 expression has been previously demonstrated to be able to efficiently cause the interruption of DNA replication (6), cell cycle arrest at $\mathrm{G}_{1}$ phase and inhibition of cellular proliferation $(6,10,11,21)$. By contrast, the overexpression of CIZ1 was able to significantly increase cell proliferation $(10,11,21)$. CIZ1 may directly promote LSCC cell proliferation by mediating DNA replication initiation and $\mathrm{G}_{1}-\mathrm{S}$ phase transition. In addition to regulating the cell cycle, CIZ1 is involved in several lung cancer-associated signaling pathways. It has reported that the estrogen receptor is activated in non-small cell lung cancer $(22,23)$, and the CIZ1 gene has been demonstrated to be a downstream target of estrogen receptor (24). The Wnt signaling pathway is activated in LSCC (25), and this may be activated by CIZ1, which interacts with transcription factor 4 to induce the transcription of Wnt 
signaling targeted genes (10). Thus, CIZ1 may promote the growth of LSCC through multiple pathways.

Elevated CIZ1 expression has been observed in a variety of types of cancer (9-14). However, to the best of our knowledge, the expression of CIZ1 in tumor vessels has not been reported. The present study revealed that the expression of CIZ1 is barely detectable in vessels of normal lung tissues but is markedly expressed in vessels of LSCC samples. Tumor vessels deliver oxygen and nutrients, which are essential for tumor cell growth, and provide avenue for tumor cell metastasis (26). Angiogenesis, the growth of capillaries from existing vessels, is critical for tumor growth and metastasis (27). Without angiogenesis, tumors cannot grow $>2 \mathrm{~mm}^{3}$ or metastasize to distant tissues (26). The function of CIZ1 in vascular cells is largely unknown. Considering its role in DNA replication initiation and cell proliferation, the overexpression of CIZ1 in vascular endothelial cells or smooth muscle cells may increase proliferation and enhance the branching of microvessels in tumor cells. However, the molecular mechanisms that underlie the role of CIZ1 in angiogenesis require further investigation.

p21 $1^{\text {Cip1/Waf1 }}$ binds and inhibits CDK1, CDK2 and CDK4/6 to regulate multiple biological activities, including DNA replication, cell cycle progression, proliferation, differentiation, apoptosis and DNA damage repair. In cancer, p21 $1^{\text {Cip1/Waf1 }}$ is closely associated with tumor cell growth, migration, invasion and drug resistance $(28,29)$. Generally, p21 $1^{\text {Cip1/Waf1 }}$ expression is considered to be a predictor for favorable prognosis in non-small cell lung cancer $(15,16)$. p $21^{\text {Cip1/Wafl }}$ expression is reduced in stage III, compared with stage I or II of disease. Positive expression of $\mathrm{p} 21^{\mathrm{Cip} 1 / \text { Waf1 }}$ is associated with higher survival rate $(15,17)$. The expression of $\mathrm{p} 21^{\text {Cip1/Waf1 }}$ is regulated at the transcriptional level by p53 or p53-independent factors, and at the post-translational level through FK506-binding protein-like, $\mathrm{SCF}{ }^{\mathrm{SK} 2}$, CR14 ${ }^{\mathrm{CDT} 2}$ or $\mathrm{APC} / \mathrm{C}^{\mathrm{CDC} 20}$ mediated proteasome degradation (28). In the present study, it was identified that $\mathrm{p} 21^{\text {Cip1/Waf1 }}$ was significantly decreased in LSCC samples, supporting the role of $\mathrm{p} 21^{\mathrm{Cip} 1 / \mathrm{Waf} 1}$ as a tumor suppressor (14). The decrease of $\mathrm{p} 21^{\mathrm{Cip} 1 / \text { Waf } 1}$ protein may be associated with overexpression of CIZ1 in LSCC tissues. The C-terminus of CIZ1 binds with $\mathrm{p} 21^{\text {Cip1/Wafl }}$ to promote the export of $\mathrm{p} 21^{\mathrm{Cip} 1 / \mathrm{Waf} 1}$ from the nucleus to the cytoplasm (4), which facilitates the proteasomal lysis of $\mathrm{p} 21^{\text {Cip1/Waf1 }}$. Taken together, it is hypothesized that CIZ1 contributes to the development of LSCC by interacting with $\mathrm{p} 21^{\mathrm{Cip} 1 / \text { Waf1 }}$.

To summarize, it was identified in the present study that CIZ1 expression was elevated in tumor cells and vascular cells of LSCC compared with normal lung tissues or adjacent normal tissues. The level of CIZ1 expression is associated with LSCC staging. In addition, the CIZ1-interacting protein $\mathrm{p} 21^{\mathrm{Cip} 1 / \text { Waf1 }}$ is decreased in LSCC. The present study indicates that CIZ1 might be considered as a biomarker for LSCC diagnosis and as a therapeutic target.

\section{Acknowledgements}

The present study was supported by a grant from the National Natural Science Foundation of China (nos. 81370269, $81570255)$. The authors are grateful for the support from Shandong Taishan Scholarship.

\section{References}

1. Siegel R, Naishadham D and Jemal A: Cancer statistics, 2013. CA Cancer J Clin 63: 11-30, 2013.

2. Kumar V, Abbas AK and Aster JC: Robbins basic pathology. Elsevier Health Sciences, 2012.

3. Katlic MR, Facktor MA, Berry SA, McKinley KE, Bothe A Jr and Steele GD Jr: ProvenCare lung cancer: A multi-institutional improvement collaborative. CA Cancer J Clin 61: 382-396, 2011.

4. Mitsui K, Matsumoto A, Ohtsuka S, Ohtsubo $M$ and Yoshimura A: Cloning and characterization of a novel p21(Cip1/Waf1)-interacting zinc finger protein, ciz1. Biochem Biophys Res Commun 264: 457-464, 1999.

5. Liu Q, Niu N, Wada Y and Liu J: The Role of Cdkn1 A-Interacting Zinc Finger Protein 1 (CIZ1) in DNA Replication and Pathophysiology. Int J Mol Sci 17: 212, 2016.

6. Coverley D, Marr J and Ainscough J: Ciz1 promotes mammalian DNA replication. J Cell Sci 118: 101-112, 2005.

7. Copeland NA, Sercombe HE, Ainscough JF and Coverley D: Ciz1 cooperates with cyclin-A-CDK2 to activate mammalian DNA replication in vitro. J Cell Sci 123: 1108-1115, 2010.

8. Copeland NA, Sercombe HE, Wilson RH and Coverley D: Cyclin-A-CDK2-mediated phosphorylation of CIZ1 blocks replisome formation and initiation of mammalian DNA replication. J Cell Sci 128: 1518-1527, 2015.

9. Wang DQ, Wang K, Yan DW, Liu J, Wang B, Li MX, Wang XW, Liu J, Peng ZH, Li GX and Yu ZH: Cizl is a novel predictor of survival in human colon cancer. Exp Biol Med (Maywood) 239: 862-870, 2014.

10. Zhang D, Wang Y, Dai Y, Wang J, Suo T, Pan H, Liu H, Shen S and Liu H: CIZ1 promoted the growth and migration of gallbladder cancer cells. Tumour Biol 36: 2583-2591, 2015.

11. Liu T, Ren X, Li L, Yin L, Liang K, Yu H, Ren H, Zhou W, Jing $\mathrm{H}$ and Kong C: Ciz1 promotes tumorigenicity of prostate carcinoma cells. Front Biosci (Landmark Ed) 20: 705-715, 2015.

12. Kim NS, Hahn Y, Oh JH, Lee JY, Oh KJ, Kim JM, Park HS, Kim S, Song KS, Rho SM, et al: Gene cataloging and expression profiling in human gastric cancer cells by expressed sequence tags. Genomics 83: 1024-1045, 2004.

13. Hu X, Chen H, Jin M, Wang X, Lee J, Xu W, Zhang R, Li S and Niu J: Molecular cytogenetic characterization of undifferentiated embryonal sarcoma of the liver: A case report and literature review. Mol Cytogenet 5: 26, 2012.

14. Higgins G, Roper KM, Watson IJ, Blackhall FH, Rom WN, Pass HI, Ainscough JF and Coverley D: Variant Ciz1 is a circulating biomarker for early-stage lung cancer. Proc Natl Acad Sci USA 109: E3128-E3135, 2012.

15. Komiya T, Hosono Y, Hirashima T, Masuda N, Yasumitsu T, Nakagawa K, Kikui M, Ohno A, Fukuoka M and Kawase I: p21 expression as a predictor for favorable prognosis in squamous cell carcinoma of the lung. Clin Cancer Res 3: 1831-1835, 1997.

16. Caputi M, Esposito V, Baldi A, De Luca A, Dean C, Signoriello G, Baldi $F$ and Giordano A: p21waf1/cip1mda- 6 expression in non-small-cell lung cancer: Relationship to survival. Am J Respir Cell Mol Biol 18: 213-217, 1998.

17. Shoji T, Tanaka F, Takata T, Yanagihara K, Otake Y, Hanaoka N, Miyahara R, Nakagawa T, Kawano Y, Ishikawa S, et al: Clinical significance of p21 expression in non-small-cell lung cancer. J Clin Oncol 20: 3865-3871, 2002.

18. Esposito V, Baldi A, Tonini G, Vincenzi B, Santini M, Ambrogi V, Mineo TC, Persichetti P, Liuzzi G, Montesarchio V, et al: Analysis of cell cycle regulator proteins in non-small cell lung cancer. J Clin Pathol 57: 58-63, 2004.

19. Goldstraw P, Chansky K, Crowley J, Rami-Porta R, Asamura H, Eberhardt WE, Nicholson AG, Groome P, Mitchell A, Bolejack $\mathrm{V}$, et al: The IASLC lung cancer staging project: Proposals for revision of the TNM stage groupings in the forthcoming (Eighth) edition of the TNM classification for lung cancer. J Thorac Oncol 11: 39-51, 2016.

20. Liu J, Li Y and Hoh J: Generation and characterization of mice with a conditional null allele of the HtrA4 gene. Mol Med Rep 12: 6768-6774, 2015

21. Yin J, Wang C, Tang X, Sun H, Shao Q, Yang X and Qu X: CIZ1 regulates the proliferation, cycle distribution and colony formation of RKO human colorectal cancer cells. Mol Med Rep 8: 1630-1634, 2013. 
22. Kawai H, Ishii A, Washiya K, Konno $\mathrm{T}$, Kon $\mathrm{H}$ Yamaya C, Ono I, Minamiya Y and Ogawa J: Estrogen receptor alpha and beta are prognostic factors in non-small cell lung cancer. Clin Cancer Res 11: 5084-5089, 2005.

23. Schwartz AG, Prysak GM, Murphy V, Lonardo F, Pass H, Schwartz J and Brooks S: Nuclear estrogen receptor beta in lung cancer: Expression and survival differences by sex. Clin Cancer Res 11: 7280-7287, 2005

24. den Hollander P, Rayala SK, Coverley D and Kumar R: Ciz1, a Novel DNA-binding coactivator of the estrogen receptor alpha, confers hypersensitivity to estrogen action. Cancer Res 66: 11021-11029, 2006.

25. Uematsu K, He B, You L, Xu Z, McCormick F and Jablons DM: Activation of the Wnt pathway in non small cell lung cancer: Evidence of dishevelled overexpression. Oncogene 22: 7218-7221, 2003
26. Shojaei F: Anti-angiogenesis therapy in cancer: Current challenges and future perspectives. Cancer Lett 320: 130-137, 2012.

27. Owen MR, Alarcón T, Maini PK and Byrne HM: Angiogenesis and vascular remodelling in normal and cancerous tissues. J Mathematical Biol 58: 689-721, 2009.

28. Abbas T and Dutta A: p21 in cancer: Intricate networks and multiple activities. Nat Rev Cancer 9: 400-414, 2009.

29. Weiss RH: p21Waf1/Cip1 as a therapeutic target in breast and other cancers. Cancer Cell 4: 425-429, 2003.

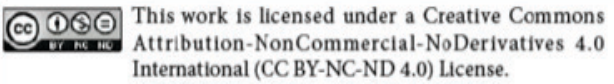

